Western University

Scholarship@Western

Aboriginal Policy Research Consortium International (APRCi)

2004

\title{
Music education in remote aboriginal communities
}

Graham Chadwick

George Rrurrambu

Follow this and additional works at: https://ir.lib.uwo.ca/aprci

Part of the Other Education Commons, and the Social and Cultural Anthropology Commons

Citation of this paper:

Chadwick, Graham and Rrurrambu, George, "Music education in remote aboriginal communities" (2004). Aboriginal Policy Research Consortium International (APRCi). 361.

https://ir.lib.uwo.ca/aprci/361 
This article was downloaded by: [University of Western Ontario]

On: 16 December 2012, At: 07:11

Publisher: Routledge

Informa Ltd Registered in England and Wales Registered Number: 1072954 Registered

office: Mortimer House, 37-41 Mortimer Street, London W1T 3J H, UK

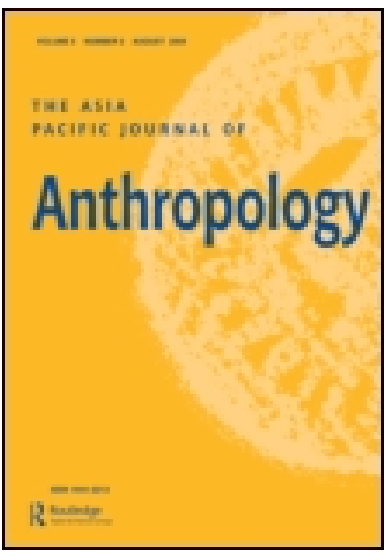

\section{The Asia Pacific J ournal of Anthropology}

Publication details, including instructions for authors and subscription information:

http:// www.tandfonline.com/loi/ rtap20

\section{Music education in remote aboriginal communities}

Graham Chadwick \& George Rrurrambu

${ }^{a}$ Northern Territory Music School, c/ o Nightccliff High School Campus, Nightccliff, NT 0810, Australia Phone: +61 (08) 89854722 Fax: +61 (08) 89854722 E-mail:

Version of record first published: 23 Aug 2006.

To cite this article: Graham Chadwick \& George Rrurrambu (2004): Music education in remote aboriginal communities, The Asia Pacific J ournal of Anthropology, 5:2, 159-171

To link to this article: http:// dx.doi.org/ 10.1080/ 1444221042000247698

\section{PLEASE SCROLL DOWN FOR ARTICLE}

Full terms and conditions of use: http://www.tandfonline.com/page/terms-andconditions

This article may be used for research, teaching, and private study purposes. Any substantial or systematic reproduction, redistribution, reselling, loan, sub-licensing, systematic supply, or distribution in any form to anyone is expressly forbidden.

The publisher does not give any warranty express or implied or make any representation that the contents will be complete or accurate or up to date. The accuracy of any instructions, formulae, and drug doses should be independently verified with primary sources. The publisher shall not be liable for any loss, actions, claims, proceedings, demand, or costs or damages whatsoever or howsoever caused arising directly or indirectly in connection with or arising out of the use of this material. 


\title{
Music Education in Remote Aboriginal Communities
}

\section{Graham Chadwick \& George Rrurrambu}

\begin{abstract}
These papers deal with some of the complex cultural and pedagogical issues involved in the delivery of a secondary-school music education program to remote Aboriginal communities. The papers outline the history of the program, the challenges in its delivery and some of the prospects for its future.
\end{abstract}

Keywords: Music Education; Pedagogy; Remote Aboriginal Communities; Arnhem Land; Central Australia

\begin{abstract}
Editor's note: The following are edited transcriptions of two papers and a general discussion on intercultural music education at the symposium 'World Music: Politics, Production, and Pedagogy', held at the School of Music, The Australian National University, on 11 October 2003. The first speaker, Graham Chadwick, is the coordinator of music education programs delivered to remote Aboriginal communities in the Northern Territory (NT) through the Northern Territory Music School. The second speaker, George Rrurrambu, was formerly the lead singer of the Warumpi Band, and is a pioneer of Aboriginal popular music who has been involved in music education for many years. Both speakers make reference to performances at the symposium by school bands from the Aboriginal communities of Yirrkala and Maningrida, NT.
\end{abstract}

\section{Graham Chadwick}

Good afternoon everyone. Today we're going to discuss the Northern Territory Remote Community Indigenous Music program, its structure and its delivery methodology. In the past three years we've experimented with several delivery

Graham Chadwick is Senior Teacher at the Northern Territory Music School. George Rrurrambu is a Yolngu musician and elder. Correspondence to: Graham Chadwick, Northern Territory Music School, c/o Nightcliff High School Campus, Nightcliff NT 0810, Australia. Tel: +61 (08) 8985 4722. Fax: +61 (08) 8948 1778. Email: graham.chadwick2@latis.net.au. George Rrurrambu, PMB 25, Barunga NT 0851, Australia. 
processes with a focus on how to engage Indigenous students throughout the Northern Territory, and how to give them similar opportunities to our regional Indigenous students and programs. How do we do that? How do we get students to be engaged with music? Also, given the major problems that we have with retention in schools throughout the Northern Territory, what are the triggers that will bring the students back to school?

With considerable program development, including the support of the teaching teams at the Northern Territory Music School, I devised and implemented a project of specialist instrumental teacher visitation, allocated in three- to four-week blocks each school term, to remote communities. Prior to this, we have gone through a process of building, and often dismantling, specialist extra-curricular programs in remote communities, which had little systemic support past the life of a short-term grant application. School-based extra-curricular activities mostly survived due to the skills associated with class-based teachers posted to the relevant schools. Students and staff would develop a community program, with the success of the extra-curricular program based on the contract life of the teacher.

As you are aware, the remote areas of the Northern Territory are difficult places to implement community- or school-based programs. A great deal of infrastructure is required just to visit remote communities, which are often hundreds or even thousands of kilometres apart.

So how do we successfully deliver the programs? The current model is based on a five-year program and operates through all remote areas of the Northern Territory, including island communities. English is often the second language within these communities, and so we had to look carefully at how we're going to develop the language of the music packages, especially the module outlines, within the $\mathrm{VET}^{1}$ Certificate 1 Music Industry package. We started by asking the music tutors and the teachers to work within the language cultures of these schools, and to identify the language base of the communities - this required the development of packages relevant to each community. It has been quite successful. Often one remote community might encompass three different language groups, and through our music packages we have developed a core of language materials to support the remote community staff. The main outcome of this program is to engage Indigenous senior students in school, and to achieve academic results through music making.

Senior secondary students would often leave formal schooling around the age of 16 or 17, having a very spasmodic relationship with the local school. This program model of block visitation over a four-term period gives continuity to the program and to the remote community schools. Students are secure in knowing the program is ongoing and sustainable over the year, and it's not just a short-term fix.

The first programs were initiated within our Arnhem Land region, which is the northeastern region of the Northern Territory. Our first pilot program was the Yirrkala Big Band, which you saw perform today. The security of the music programs requires considerable community relationship building. School principals who have foresight, drive and initiative are the key to their success, and to develop a program 
which can work efficiently with the broader educational system requires thinking outside of the square. Our biggest failings with remote community delivery is the system working against itself, rather than in partnership. To overcome this we started to look at the process of building relationships between ourselves, our remote community people, our community education centres and also the local government councils which are involved in these programs.

You may have noted [in the performances we have just seen] the high attendance of female students within the band programs. When we first started, this wasn't so-we tended to have only male students involved. Simply to perform to an audience can be an arduous and embarrassing situation for Indigenous students, but today you saw how confident the students were. When we first started the program, students would have their backs to the audience to perform. The self-worth aspect of performance has also developed the students' well-being and confidence.

The success of the program relies on having very experienced staff. Who do we get? Trained teachers? Well, unfortunately, no. Trained teachers didn't have the skills that were required to achieve industry performance outcomes. We had to look for specialist, industry-trained musicians, with the inclusion of Indigenous-based teachers. We have teachers who come from Papua New Guinea, and from all around Australia to work within this project. The aim of the program is that the students will be able to gain certification in vocational education programs. Forty students, including 24 whom you saw perform today, will soon complete the first stage of this certification, and I think that's a marvellous achievement in under twelve months.

So, where do we go from here? Now that we've designed the process, and we've built our relationships, we have to start looking at the tertiary education elements of it. In twelve months' time, we'll have 130 to 140 students who will be ready to engage in either higher-level vocational training or some formal academic music education. What we're looking for is an extension of the programs that we have developed, and we also have to build relationships nationally with institutions like The Australian National University, and with our own Charles Darwin University. We have to look at the ways that we can implement these processes in a remote delivery style-not bringing students from the communities, but taking the programs to the communities. That's the gift of these programs. Their success is that they are happening in the people's own cultures. It's all about the community life; it's about what the community holds as being important. Their families don't want to see these students as another lost generation. It's all about re-engaging kids back with school, giving the community something that really is special to them, and then taking it to the world.

One of the main outcomes... is that this is not only about teaching music. A crucial element is the application of the literacy of music, the numeracy of the notation, the songwriting programs - these are all important things to have come out of the program, and things that the teachers in the schools have linked to their own language programs and their English programs in order to develop broader educational outcomes. 
At the moment we're running 45 programs throughout the Northern Territory, some in centres that are only accessible by four-wheel drive vehicles across sandy deserts. The thing that we're seeing-our benchmark - is the success and the enthusiasm generated by these programs. When you go to a community and you see a father and son running to the music room - so that the child doesn't miss out on a music lesson - then you really know that this is something that's important to and valued by them. George Rrurrambu will tell you all about that.

There is one special program that we've developed in Alice Springs. We delivered a program to a camp which had students who were [petrol] sniffing, basically a lost generation, and out of that we established a music program in the camp itself, sitting under the tree negotiating with the elders of the community. We have a band called the Trucking Yard Band, and you'll see and hear more of that when George talks to you. The Trucking Yard students performed just last week at the Araluen Centre, they're doing a recording, and they're being employed by Amoongana community to work with their students. So not only have their lives changed, but now they're also employed.

Without further ado I'd like to introduce you to George, who is a partner in this. Who am I to go to an Indigenous community and say, 'This is what you need to do?' Part of the process is, first, to look at respected Indigenous musicians, such as George, who are the founders of Indigenous music in Australia. George is a consultant with the Northern Territory Music School, and through us, he works with the students and visits the communities. He talks to them about his life experiences, and about how music can do wonderful things for them. So I'd like to hand over to George now, who will talk to you about his personal and cultural identity with music.

\section{George Rrurrambu ${ }^{2}$}

My name is George Rrurrambu. I'm well-known as the lead singer of the famous Warumpi Band. I'm here to talk about teaching music. That's what I do.

When I'm not performing, I'm usually teaching kids in remote areascommunities - through the Northern Territory Open Education Centre, where I work. . . as a material development officer.

I want to talk. . . first about singing in the band, looking at drunk people, looking at a person 'humbugging' you down in the front - one day he's going to change, through these programs.

I also want to talk about my teachers. We are the teachers for these students. And who were my teachers, the people who taught me to sing and dance, and to play the instruments? We never used to play instruments. But I'll come back to that.

Today, we still teach our kids about ceremony, through high-level ceremony... I want to talk about it, because I was one of those who never [learnt] these instruments. Today we saw brass and trumpet. We never used to have [them] before.

I also want to talk about what we teach: and what age; how; and who from. [It's] very very difficult. So [the questions are:]: How? What age? Who from? 
Well, when I was born, [what] I first heard [was] my mother crying. ${ }^{3}$ And my mother, she never used to dump [leave] me when she'd go and visit a coffin. ${ }^{4}$ She didn't leave me and go and visit the coffin, or a body laying without a coffin. When I'm there: [sings, imitating women's keening]. That's the first tune I got-picked up - from my mum. What age - [that's what] I'm talking about what age.

And when I grew up, I saw my dad dance — singing — with the first instrument that I heard [holds up a pair of bilma, hardwood clapsticks]. So, this is bilma... it was created before I was born. And created before the new instruments introduced to me. This one [gestures as if playing a yidaki, or didjeridu], and the wooden sticks were the first instruments that my ancestors used.

And as we can see, they matched that stick. Who can tell me, what's wrong with this size [referring to difference in size of two bilma]? One short, one long. What's it mean? Anybody know what it means? It was made [like that] in the beginning [of creation], and today we still use big and small. It means: this one is my baby [holds up the smaller bilma]; it means this one is my mother [holds up the larger bilma]. [Beats the bilma together once.] Sounds different.

So, these were my first instruments, before those things [the Western instruments] ${ }^{5}$ came to me. So, that's how I learned. And before learning comes respect, and the Yolngu culture, law and rom, [is] very strong in the Top End area and Central Australia - very strong. Two to three months - they go in the jungle. [Maybe] for six or twelve months. Learning respect. That's why sometimes we see, first, kids when they play [mimics dancing] — rock and roll. When, after business, ${ }^{6}$ coming back from business, we usually don't stand straight [pretends to stand with an uncomfortable groin]. We don't move. OK? Because, respect and, law. Yolngu law comes first.

[At] present, we have proper music teachers in our schools. We have started music courses in our community education centres all over the Northern Territory. And in the Northern Territory, you can see those [gestures to map], if you go to Darwinthere's some people working in the Darwin area, especially Ludmilla - where Graham Chadwick worked with DEET, Department of Employment, Education and Training. What we have today is a proper instrument. . I was very surprised when I saw those kids back at the community, pulling up this brass - I don't know how to use it. They taught me. I said 'How do you use that thing?', 'You play like a didjeridu.' So I did it [mimics playing]. I did it. Sound came out.

Music training courses are now taught through Northern Territory University, Northern Territory Open Education Centre, Vocational Education and Training, and DEET. $^{7}$ Four [places]. And we're separate. . The university goes to places in remote areas. Some university people go, because I tell them, 'There are bored boys over there in the community, bored, and the ladies, bored, they're not doing any work, they're getting into grog, they're getting into drugs, they're getting into marijuana. Stop them before they get worse.' And there are the $\mathrm{CECs}^{8}$ in the remote areas, today, that are now learning...[using] the music training package that I work through with the Northern Territory Open Education Centre. 
Look at the Yirrkala CEC. And Maningrida CEC. Barunga CEC. Elcho Island, Galiwin'ku CEC. Lot of good music is coming from these communities.

Look at the map. Northern Territory University entry-level music course. Well, they were taking the music course to remote areas, not only music studies, but we all come together as one. Like Ben, ${ }^{9}$ he plays in Yothu Yindi band, myself, some in the Wirrinyga Band, we all work together...If we look at the Alice Springs Trucking Yard - these kids have never been to school, they never go to school. And what they found, through their ears, and grab[bing] instruments, this is what we get [refers to video clip of young musicians of the Trucking Yard Band]. That they can just straightaway play. And they don't go to school. And Graham [Chadwick] went to visit them, there, and this is what he found. One of those Indigenous persons working with them is one of my bass players. He's one of my bass players. Working with these people.

I went to Elcho Island, for a holiday. . . and I found bored kids over there. And they had songs - they had music-but how are they going to make it into the mainstream? So they saw me, coming down from the plane, 'Ah, this guy's going to help me.' They thought I'm coming there to work, but I'm there to visit my dad-I hadn't seen my dad for five or six years. So when I got there, they have the music all ready, and the songs, but where's the music, where's the sound? So I sat down once and wrote songs with them. I was there when the course first came to Elcho Island. All the musicians who were sitting around waiting for equipment so they could play, suddenly came to the course, every day, and formed a new band, and wrote, and recorded new songs. Me and my brothers, two of my brothers, and two of my cousins, we formed a band. Because I thought Warumpi Band ${ }^{10}$ was going to be dead. So I formed a band, just to encourage my brothers, my cousins. And I called that band My Boys Are Good Boys. My Boys Are Good Boys. . .I remember that word [phrase], 'my boys are good boys', came from the grog country. Like, 'Don't be violent, let's sit down without any fights, my boys are good boys. You fight, my boys are good boys.' You know?

I started helping my family through my hardship, 25 years just looking around, looking around. 'What's going to be happening for those future kids?' And I was running around, 'Who's going to be the person like me, in the future, to show [them]?' Because I was the first person to come up with the message of: 'When are you going to stop drinking? When are you going to stop going into jail? When are you going to get frightened of all this stuff?' Because I was the one-you wouldn't believe me. I was the worst drinker. . You want me to tell you? I got duplicating fluid, I got in me [consumed]. . .that clear solution, I thought it was good, so I mixed it up with milk, and I drank it. That's what I got. I got methylated spirits. I got petrol - just like I'm a car. All that stuff I went through when I was young. I grew up, I grew up, I grew up, I grew up. Finally I recognised that I was doing the wrong thing.

The first education I had was going into the Batchelor College, ${ }^{11}$ to learn language. Totally another language. So I passed [studied] that language [for] one year. I wanted to learn Warlpiri language. Warlpiri was very, very, very, very recognised in the 
Darwin area, because a lot of Warlpiri people were hanging around there. So I started to learn language-Warlpiri language. And that took me to the Centre, where I finally ended up making a band.

So, doing that music, we recorded an album at Maningrida. Sunrize Band ${ }^{12}$ was there, Letterstick Band ${ }^{13}$ was starting to come, Saltwater Band ${ }^{14}$ was starting to come, My Boys was starting to come, some new bands were starting to come. Yes, Sunrize hit Sydney. Saltwater hit Sydney. Nabarlek ${ }^{15}$ [is] now [a] big band. And they started, we started together. Me and Mandawuy, ${ }^{16}$ we didn't go to school through music [learn music in school]. So our music was recognised and grew up, and grew up, and grew up, and grew up. And when it was growing up, I started to give up the grog, maybe 15 years [ago], I did it. I did it well. Nearly 25 years now, 25 years in the band, 15 years off the grog, and I'm fine.

So innovating and creating, teaching methods, this is what I do. The way I teach, first, I want to see action. And what is the action? If I teach my kids and walk away, never worry about them, they end up in what? They end up on the grog, they end up on the street. They end up hanging themselves. So this is what I do. When they end up doing crimes, 'action' means let's see them using the equipment, what we saw today. They were using the equipment. . And in the near future, we want to see them supporting Rrurrambu or Yothu Yindi or Nabarlek, or some American artist, or international artist coming in. These are the kids and we've got to be supporting them in the near future. With their own message.

I also teach them about APRA ${ }^{17}$ and AMCOS. ${ }^{18}$ When they develop the musicwhen they write the music, where is that music going to? I teach them...to go through the right channels. This is the channel I talk about. Go through APRA and AMCOS, and get a licence, like I've got, somewhere here [pats shirt pockets], green little slip, card. So, [it's] not just talking about the music, it's also talking about what they'll be receiving from what they're touching. I did it. I did it a lot of times. There's a lot of clothes, [I have] flash clothes on, 'Why did you buy this?' 'Because I sing. And get money. And buy clothes.' 'You've got flash shoes.' 'Yeah, I sing, so I can buy those shoes.' So, I'm teaching them to continue, continue, continue to the end.

There is a lot of opportunity in the future for traditional and contemporary performance. The Aboriginal music industry will grow. Will grow, will grow, will grow, and grow.

What inspired me?...Well first, stories of my ancestors. My grandfather's and his family's story. For example, for a song called yibula ${ }^{19}$ I wrote when I went to Elcho Island. Yibula means...[takes off jacket to reveal vest with Aboriginal flag embroidered on the back]...this flag here. Yibula is about this flag. Why yibula? Well, first, when [the] first visitors came, they brought this cloth for us. And you know who they were? They were not Dutch, they were not English. They were all Macassans. ${ }^{20}$... And they gave us these materials - to every traditional country - as a gift, as their exchange. So...I wrote special songs for this, about this [yibula]. And traditional people, red flags: [the] Dhalwangu tribe. Red is the Dhalwangu tribe. Yellow represents Gumatj tribes. Black represents Warramiri tribes. And we dance and 
sing — so those new kids can grow and look, and they'll start dancing. And it's still education, through contemporary and traditional [means].

Now we're getting into action. They are now playing. We saw them. They sound beautiful. Right? And they are only from two communities, Yirrkala and Maningrida. And there's some kids in Roper River where I work, and [I] sit down with them. There's kids at Numbulwar who I sit down and work with. I'm there to encourage them, to say, 'What is your music? And how [do] you sing it?' And 'That's good. Beautiful. Let's see you on the main stage'... In Alice Springs today, and in the Top End, we're all working, and from last year, we have a number of students. Now these kids [are] going to be getting their first... [to Graham] what, certificate? Certificate. From working. And I hope, in the near future, they will be our teachers, because they are going through the right school. Right? These kids are going through the right school. And those kids back there [at the back of the room], they're going through the right school. What we need is support on this project. We need support, so we can get both, your colour and my colour [in the] near future working together as a partnership.

When I first started, I was 11 years old. And I remember, we used to sing, sing like this, kids, I used to stand like this [mimics standing very upright with hands clasped], and look at the conductor - that's what I learned. And look [mimics posture again]. And [the] first song I sang was... [sings in a loud, high voice] 'Silent night! Holy night!'

Thank you.

\section{Open Discussion}

Karl Neuenfeldt (Central Queensland University): How do you supply instruments and strings and all the accessories, get them into the community and keep them up so that everything is playable? That's a community responsibility?

Graham Chadwick: It's a school responsibility. We have a program where we do a 50/ 50 costing with the communities, and the instruments are kept at the school. So it's all based through the school rather than the community. And we have success with that, and when our staff are travelling, every term, there's regular maintenance; that was a problem, you know, probably five, four years ago, where instruments would be lost or damaged, but now it's regularly maintained. But also the students, now you can see that they own their own instruments as well, so in that short two-year period that we've been developing the program, the ownership's quite strong about, 'Hey, I'm a musician, and this is my equipment.' So, a lot of that has come into play now as well.

Howard Morphy (The Australian National University): After the certificate that they're doing this time, how does the program carry on developing, and, as you get more students involved, won't that start putting pressure on the music teachers who are there? Have you got a plan ready for expanding in that sense? 
Graham Chadwick: Well, the difficulty with what we're doing now is that there is a shortage of highly qualified staff to do this kind of work, so we're looking to work with universities to develop training in this area. And the beauty of that is that it will be a side-by-side process, because a lot of these students are now one year from engaging in some tertiary development. So, these are the students and the teachers of the future, who we will keep in the communities, train them and pay them as teachers within our own department in the Northern Territory. So, the options are that it's not always that they're going to be a star, or a musician - that might happen, but the opportunities are far more widespread having three or four of these students in each of their communities as teachers. That's what we're looking for, and the structure of ongoing assistance of us coming in and offering training will take the pressure off. Actually, if you saw the guitarist in the first band-Travid is his name-he works with our staff member, Scot Trenwith, who works at Maningrida school. So these are the guys who do the work, and it's all about putting in place an assistance structurethat will give them the opportunities to move forward.

Louise Hamby (The Australian National University): George, I wanted to ask you a bit about any sort of involvement and what the relationships are with some of the girls, because we've noticed today, particularly in the Yirrkala school band, there were girls playing. When you're out working, are you only working with the boys, or do you work with girls as well, or how do you see the girls becoming involved in programs who aren't already?

George Rrurrambu: That's what the program is all about. Teaching the kids, both boys and girls. And we don't separate them [conceptually]. Sometimes we separate them [physically], sometimes we put them together, like, their big band, especially at Yirrkala. But, yes, we do separate them in the band at Roper, ${ }^{21}$ they have their own band, the girls have their own band, 'Shady Girls'. The boys have four bands. And yeah, we do teach them both to get into the roles, like Christine Anu and George Rrurrambu, and all this.

Graham Chadwick: And also there're the protocols of working in a community with a band, I mean, you see a group of boys and girls performing, and in that one band might be poison cousins, so they're never allowed to stand next to each other, although one can be at one end of the band away from the other - so there's a hierarchy and a protocol just within the band. And also, the fact that you have to work with the Indigenous elders, the ladies in the community, who say, 'No, they can sing this song outside of Yirrkala, but they cannot sing that song in the community.' Because it's deemed not appropriate for girls if they dance too much or they move too much. So there're a lot of protocols within one band, so there are many things that you have to work with to move forward.

Stephen Wild (The Australian National University): Can I ask, George, do you have a lot of support from the older members of the community, or do some of them resist this?

George Rrurrambu: Ah, yeah, I do get a lot of support from my elders. What they say is, 'George, you are doing. .. [an] enormous job-excellent - to stop the kids from 
touching the stuff [alcohol or petrol], and getting sick to it'. Yeah, I do have support from my elders, especially those people who are the 'business' men. I do ask them, and talk to them, about teaching in the Indigenous way, Yolngu way, blackfella way. Stephen Wild: Do they come into the school and help you sometimes?

George Rrurrambu: Yeah. Witiyana ${ }^{22}$ came, and some traditional people from Yirrkala came and saw me, and were very happy with me. Lake Evella, ${ }^{23} \mathrm{I}$ went to visit in Lake Evella, the people over there, traditional people, came to me first and said, 'You're very lucky to come here. We really want you to encourage these people.' I went to Numbulwar, and I found out 'Hey' - respect. They had big respect for me because they knew who I was, coming into their yard. So yeah, I get a lot of support from the whole of Australia, all around Australia, especially old people, who have the brainnever damaged.

Simone de Haan (The Australian National University): To what extent do you feel there is the possibility to work with the students in supporting a strong connection with their own traditional music while teaching them contemporary music skills, building on the aural connections - which is where their own music is coming from anyway-integrating the two musics naturally, not through an imposed integration, through listening, in an unspoken way?

Scot Trenwith (Maningrida Community Education Centre): I think that's happening, but I don't think that's our place. I think that what we can offer is alternatives. We can offer: 'This, have a look at this way of doing it, have a look at 6/8 time, have a look at this, break out of the chords with trumpet and play a jazzy solo, see if you like it.' For working out brass lines, I work with Travid [Darcy, and Aboriginal student teacher at Maningrida], I give him multiple choice. I don't think it's our place- the traditional stuff is so strong, and it's been transmitted so strongly, and these guys are so strongly imbued with it. They live it. My friend came and stayed with me from Galiwin'ku, he's a didj player, I went to a funeral for four days last week with him. It just continually blows my mind, the strength. He's my age, and he's a professional yidaki player - they pay him to do ceremonies. It's there. I think in the last 15 years, I've played with a Yolngu band for a few years; what we see is more and more of a subtle integration of the local complexities and sophistications in the local music. We look at a band like Saltwater Band from Galiwin'ku - their latest songs, if you transcribe the words, they read like a bunggul, ${ }^{24}$ they read like a traditional song. Where, say, ten years ago, it wasn't really even thought of to do that kind of thing. They list place names, the whole grammar structure, words, it's almost like a traditional song.

Simone de Haan: So, in a way, it is moving forward.

Scot Trenwith: I think it's just, evolution takes its course, and we can offer school, and we can be part of all that by offering alternatives, extra things. 'Try this! What do you think? Let's change between five [5/8 time] and three [ $3 / 8$ time], let's try that, that's pretty outrageous.' But it's not outrageous, because they were doing it yesterday at that funeral.

Jo Taranto (Yirrkala Community Education Centre): Something we've thought of is for them to study the Saltwater Band music, and get Yolngu to explain what's actually 
going on in it. What it's talking about. Because, they're these musicians, and they've been aware of what other people are doing, because Saltwater Band have got to be better teachers than us.

Scot Trenwith: It's happening. We can offer whitefella skills, us whitefellas who are working there, and then the locals can...it's happening.

Howard Morphy: But you could argue the ideology of the Yirrkala school and the two-way education, as Jo mentioned. That, in fact, explicit from the community's viewpoint is not to exclude that form of knowledge from the school, because, although it can look from the viewpoint of Maningrida at a particular point of time that everything is being taken care of in the Indigenous way as far as music is concerned, the history of Australia is that actually that hasn't been the case. Certainly the idea of two-way education coming from people like Mandawuy, ${ }^{25}$ and Raymattja, ${ }^{26}$ was that if you didn't include Yolngu knowledge systems and Yolngu language within the school, then, although it looked very strong, it could in fact easily be threatened. So, I think that it's not necessarily incompatible to have both a very strong Indigenous context for musical performance and learning, but at the same time allow the school, depending on what the community wants, also to be involved in that particular form of teaching. And doing it in different ways, and learning both ways.

Scot Trenwith: They don't have a burning need to do 3/8, 5/8, 3/8, 5/8, in their rock and roll, because they're completely satisfied with doing it in bunggul. And they do it often enough, and they do it so powerfully, and it does have such a strong effect when they do it there, that it's us who have the burning desire for them to take it and put that level of sophistication in their rock and roll. That's us. It's not really them, because they've got it. We want it. They've got it.

Stephen Wild: You sort of paint a rosy picture, and I'm just trying to put my finger on any difficulties that you have, since you haven't talked about any difficulties much. One of the potential difficulties I see, and Louise Hamby referred to it earlier, is the gender issue. Because it was very noticeable, for example in the Maningrida band it was all boys...

Scot Trenwith: Only because the girls are going to Sydney for volleyball in November. We've got a girls band. But they were too busy, they're too good at volleyball.

Stephen Wild: Are there any issues of them mixing, boys and girls in the band?

Jo Taranto: There is definitely. The best thing at the moment is, we've had all these issues, and we've gone now to - there's a boy's band, there's a girl's band, there's a mixed band, and there's a young band. And it is different kids who are shining in different bands. Some of those boys who really stand back are the lead people in the young band. And then some of the girls, who are more of the singers, will go, 'Right, here's my chance to play something else in the mixed band.' And some people have got that really strong brother-sister thing, so they're playing that instrument so they can't stand next to them, and so someone will change across, and you suddenly see these other people move, and it's like, 'Why isn't this main person. . .?' And so I think 
it's just the fact of having these different opportunities in different bands, and people know that they've got different roles.

Stephen Wild: Can I just make an observation, and I may be way off the beat, but this is what I observed, anyway, and maybe I'm over-interpreting. But in the Yirrkala Band, I noticed that it was the boys who played the main instruments. It was a boy who played the synthesiser, it was a boy who played the drums, it was a boy who played rhythm guitar, it was a boy who played lead guitar, and the girls were relegated to the brass instruments, and that's all-they could just play now and then. There was one occasion in which that changed, and that was with the last piece, when a girl played rhythm guitar. But it seemed to me that the boys were taking the key instruments in a rock band. That's the sort of issue that I thought might come up. And I interpreted that to be a reflection of the segregation in traditional life.

Scot Trenwith: There would be two factors, I think. One, we started the girls and boys off together. Both at Yirrkala and at Maningrida, I had an agenda of wanting to give girls a chance to play, as well as most other people. At Maningrida the boys started first, and the girls started with me a year later. At Yirrkala they started together. The boys took it up very quickly, and the girls took it up slowly, because it was a completely new thing, girls playing rock and roll instruments. I think the first girl's band ever in Arnhem Land was the Yirrkala girl's band...So, the boys took it up quickly, they grabbed it, jumped on it. But the girls, slowly, slowly played away, and then they became a band, a solid girl's band. And then there's also the fact that, when boys and girls play music together, the boys will take the front and the girls will take the back.

Amanda Reynolds (National Museum of Australia): What about having male and female teachers and role models from the community who are coming and teaching? When you've got more of the older women from the community participating, does that affect how willing the girls are to participate?

Dale Pascoe (Maningrida Community Education Centre): Well, in our culture, it's really strong that the men sing and dance, but the women, they can dance but they can't sing. What you have seen is that the girls are playing the bass, the brass - it's a new generation, that the girls are involved with the musical instruments. But in our culture, for example, if I'm singing down here in front, and my sister's playing brass or something, I don't want to see that, you know, it would sort of embarrass me.

Scot Trenwith: There's a special relationship between a man and his sister.

Dale Pascoe: Because, in our culture, it's really strong, but now, the new generation...comes. It's, 'OK. Let's teach the girls, only the boys can play guitar, let's try and do new things.' You know? It's not coming out of our people, it's a new thing that's coming out of the balandas, ${ }^{27}$...that's the new generation.

\section{Notes}

[1] Vocational Education and Training.

[2] In this transcription, an ellipsis is used to indicate a pause of $2-3$ seconds. 
[3] Ngäthi is a word in Yolngu languages of northeast Arnhem Land which refers both to crying and to a form of women's singing.

[4] That is, visit the body of a deceased person, lying 'in state' during a funeral ceremony.

[5] Western instruments, of the type the students played earlier in the day.

[6] Initiatory ceremonies, which include circumcision ceremonies.

[7] The Department of Employment, Education and Training in the Northern Territory.

[8] Community Education Centres.

[9] Ben Hakalitz, drummer for Yothu Yindi, and consultant music teacher.

[10] A well-known band from Papunya, NT, who released the first-ever Aboriginal-language song in Australia, 'Jailanguru Pakarnu', in 1983.

[11] An Aboriginal training college in Batchelor, NT.

[12] Aboriginal band from Maningrida, NT.

[13] Aboriginal band from Maningrida, NT.

[14] Aboriginal band from Galiwin'ku (Elcho Island), NT.

[15] Aboriginal band from central Arnhem Land.

[16] Mandawuy Yunupingu, lead singer of Yothu Yindi.

[17] Australasian Performing Right Association.

[18] Australasian Mechanical Copyright Owners Society.

[19] A word in Yolngu languages which means 'flag'. Among Yolngu people, flags are objects of cosmological and ritual importance.

[20] Traders and fishermen from the port of Macassar in southwest Sulawesi visited the Arnhem Land coast between the mid-1700s and the early 1900s, harvesting trepang for export to China.

[21] Ngukurr, NT.

[22] Witiyana Marika, formerly of Yothu Yindi.

[23] Gapuwiyak, NT.

[24] Bunggul is a traditional musical performance, usually involving dance.

[25] In addition to being the lead singer of Yothu Yindi, Mandawuy Yunupingu is also notable for having been the first Aboriginal principal of the Yirrkala school.

[26] Raymattja Marika, a prominent teacher, linguist and educational theorist at the Yirrkala school.

[27] Balanda is a word in a number of Arnhem Land languages which refers to Europeans. 